\title{
РЕЦЕНЗІї
}

() Андрій Федорук* (Чернівці)

\section{ДОСЛІДЖЕННЯ ПРО МІЛІТАРНИЙ СЕГМЕНТ ГЕТЬМАНСЬКОГО ДВОРУ В РАННЬОМОДЕРНІЙ УКРАЇНІ}

Рецензія на книгу: Олексій Сокирко. На варті булави. Надвірні війська українських гетьманів середини XVII - другої половини XVIII ст.: науково-популярне видання. - К.: Темпора, 2018. - 184 с.: іл.

Відзначаючи здобутки сучасної вітчизняної історіографії з воєнної проблематики козацької доби, необхідно сказати, що на сьогодні найбільш плідну наукову роботу з ії вивчення проводить О. Сокирко, нове цікаве дослідження якого нещодавно побачило світ у київському видавництві «Темпора». Зазначимо, що з ним автор рецензованого видання уже віддавна успішно співпрацює, публікуючи свої праці з вищеназваної тематики. Саме в ньому були надруковані його попередні книги: «Лицарі другого сорту. Наймане військо Лівобережної Гетьманщини 1669 - 1726 рр.» (2006), «Конотопська битва 1659 р.: Тріумф в час Руїни» (2008) та «Український рубікон. Полтавська битва 27 червня 1709 р.» у 2-х частинах (2009). Як і два останні названі видання автора, пропонована до уваги читачів його нова книга також з'явилася у серії «Militaria Ucrainica», котра наразі уже $€$ справжнім циклом науково-популярних робіт з воєнної історії України різних періодів та епох.

Чергова книга О. Сокирка присвячена одному маловивченому аспекту в мілітарній культурі козацької доби - гетьманському надвірному війську. Як слушно зауважив автор, «гетьманський двір, як політичний інститут і водночас складний соціально-економічний організм, тільки останнім часом став об'єктом самостійного вивчення у науковій літературі» (с. 14) ${ }^{1}$. При цьому я погоджуюся 3 думкою дослідника, що некоректно розглядати надвірні військові формування як структурну частину збройних сил Гетьманщини, оскільки і за характером свого функціонування, і за способом утримання воно значно більше залежало безпосередньо від очільника Козацької держави. Для порівняння автор рецензованого видання наводить приклади, коли у державах стародавнього світу та середньовічних монархіях прибічна варта можновладця проходила відповідний еволюційний шлях перетворення в особисту гвардію - елітну частину, яка виконувала не тільки бойові та охоронні завдання, але й також могла активно брати участь в адміністративному державному управлінні. Тому гетьманські надвірні військові формування займали проміжне становище між власне двором українського зверхника та збройними силами Гетьманщини. «Із двірським середовищем, - на думку О. Сокирка, - його насамперед поєднували репрезентаційні функції, однак у Козацькому Гетьманаті, аж до епохи Розумовського, надвірні війська ніколи не належали до складу самого двору та не фігурували у розпорядженнях по його управлінню» (с. 17). Водночас автор книги не пояснив, у чому були суттєві відмінності між надвірними військовими формуваннями та найманими (охотницькими) полками, котрі також були дуже залежні від рейментарського двору в питаннях свого управління, матеріального постачання та грошового забезпечення. Цей аспект так і не знайшов рельєфного висвітлення у рецензованому виданні.

Розкриваючи початки гетьманського надвірного війська в період Хмельниччини, дослідник правильно зазначає, що «подібно до історії інших інституцій новопосталої держави, губляться в мороці перших років Козацької революції» (с. 18). Проте йому вдалося, грунтуючись на відповідних повідомленнях $з$ різних історичних джерел, віднайти факти, що засвідчують існування при боці

* к.і.н., доцент кафедри історії України Чернівецького національного університету імені Юрія Федьковича.

$\mathrm{PhD}$ in History, Associate Professor, the Department of History of Ukraine, Yuriy Fedkovych Chernivtsi National University.

orcid.org/0000-0002-1305-4898

E-mail: andrii.fedoruk12@ukr.net

1 Тут і далі посилання на відповідні сторінки рецензованої книги. 
першого очільника Гетьманщини власного збройного почету, який здійснював охоронні функції. Далі автор докладно висвітлює, як цей загін поступово перетворився на окреме надвірне військо українського зверхника. Багато уваги приділяється аналізу його етносоціального складу, внутрішній організаційній структурі, озброєнню і тактиці ведення бою тощо. Стисло висвітлюються події, в яких простежуються різні форми діяльності «гетьманських преторіанців». Однак у кінці цього розділу своєї праці О. Сокирко робить не до кінця зрозумілий висновок, за яким виходить, що «подібно до античних володарів і середньовічних монархів, козацькі зверхники оточують себе іноземними найманцями, не зв'язаними з місцевим населенням та старшинською фрондою» (с. 33). Варто було навести якісь конкретні порівняльні приклади, бо таке нічим не підкріплене твердження викликає тільки додаткові запитання до автора, на які останній не може дати відповіді читачеві. 3 прочитаного в цьому розділі книги більше проступає, що в період Хмельниччини було покладено початок формуванню гетьманського професійного війська як певного відгомону європейської «мілітарної революції».

Остаточне інституційне утвердження надвірних військових формувань, на думку автора, відбулося у період Руїни, саме тоді, через постійні внутрішні заколоти і зовнішні інтервенції, боротьбу численних претендентів за булаву та криваві гетьманські усобиці, у можновладців з'явилася дуже нагальна потреба в стабільній і надійній збройній опорі. Зокрема, як вказує дослідник, «про кількісні розміри гетьманського двору та його супроводу поза чигиринською резиденцією можна судити і з повідомлень про виїзд Петра Дорошенка в Канів у січні 1673 р., де мало відбутися весілля його дочки та Юхима Лизогуба. Очевидці цих подій повідомляли, що гетьман прибув у місто «в тысяче конех» (с. 34). Автором простежуються особливості формування у цей складний період вітчизняної історії гетьманських надвірних військ на Правобережжі, де була можливість затягнення на службу контингентів 3 різних іноземних елементів, та Лівобережжі - там наймані частини створювалися переважно 3 місцевих вихідців. Особливо багато уваги автор приділяє військовій діяльності Івана Виговського, за гетьманування якого розроблявся відповідний план реорганізації збройних сил Козацької держави. Згідно з ним, «при збереженні станового козацького ополчення, розбудовувалося б нове постійне професійне військо на зразок кварцяного, що існувало в Польщі» (c. 37). Проте навіть опора на надвірні військові формування не гарантувала повну безпеку українським зверхникам, про що свідчить сумна доля гетьмана Дем’яна Многогрішного.

Чимало місця в своїй роботі О. Сокирко приділив часам Івана Самойловича й Івана Мазепи, які стали дійсно справжнім «золотим віком гетьманських гвардій». Це була епоха, коли, за словами автора, «Гетьманат увійшов у період соціально-політичної та економічної стабільності, а рейментарський двір набув свого класичного вигляду» (с. 76). В цей період надвірні військові формування уже більше займаються організацією безпеки гетьманського двору, хоча водночас вони брали участь і в кампаніях, якщо сам український зверхник безпосередньо керував виправою. Так було в період Чигиринських походів 1677 - 1678 рр., Кримських походів 1687 і 1689 рр., Дніпровського походу 1695 р. тощо. На думку дослідника, саме у ці часи «надвірні контингенти разом із найманими полками утворили військо, паралельне козацькому, але залежне й підконтрольне лише гетьману, котрий утверджував свою владу, не зважаючи на прояви старшинського невдоволення» (c. 95). Усе це тільки свідчило про остаточне перетворення надвірних військових формувань на важливий мілітарний сегмент такого політичного інституту Козацької держави, як рейментарський двір. І тільки події 1708 - 1709 рр. внесли корінні зміни, які суттєво позначилися на майбутньому становищі «гетьманських преторіанців».

Велику увагу приділено в рецензованому виданні подальшій долі надвірних військ українських зверхників після Полтавського розгрому. Майже половину книги складають відомості про останні наймані полки, засеймські сотні та рештки жолдацької команди від періоду гетьманування Івана Скоропадського до часу правління Кирила Розумовського. Цьому, очевидно, посприяли численні документальні свідчення, які збереглися у відповідних фондах вітчизняних архівосховищ. Грунтуючись на них та інших даних з опублікованих джерел, О. Сокирко зумів встановити, що регенерація гетьманських військових формувань у колишніх масштабах і формах відбулася уже в часи Данила Апостола, стараннями якого було відновлено кінну надвірну хоругву. Проте, за твердженням автора, «відроджена надвірна хоругва, як і все надвірне військо, тепер остаточно втрачає своє бойове значення. Колись грізну силу відбірних гетьманських жовнірів змінює ефектна почесна варта. 
Замість далеких і небезпечних виправ, участі в битвах і справжньої, а не церемоніальної охорони особи і двору ясновельможного, надвірні компанійці їздять «для посилок» за різними дорученнями гетьмана та придворних, адміністраторів рангових маєтностей, ГВК, супроводжують гетьманських дворян і конвоюють злочинців» (с. 112). Багато уваги присвятив дослідник висвітленню питань грошового і матеріального утримання, «мундирному платтю» і озброєнню надвірного війська періоду занепаду Гетьманщини. Особливо докладно усі ці організаційні аспекти розкриті в розділі, де автором висвітлюються аспекти, пов'язані з лейб-гвардією та іншими надвірними військовими формуваннями останнього українського зверхника, що існували у $1750-1768$ pp.

Насамкінець варто підкреслити, що загалом нова книга О. Сокирка містить висвітлення дуже важливого наукового питання, добре ілюстрована кольоровими реконструкціями і чорно-білими малюнками, що розширює можливості осягнення значного фактичного матеріалу, і безперечно зацікавить не лише фахівців, а й усіх поціновувачів історичної минувшини українського народу. 